УДК 378+37.09

DOI https://doi.org/10.24919/2308-4863/41-2-38

Olha NESTEROVA,

orcid.org/0000-0002-5952-4664

Candidate of Pedagogical Sciences, Associate Professor, Associate Professor at the Department of Translation

Dnipro University of Technology

(Dnipro,Ukraine) olnesterova@yahoo.com

\title{
TRUST AND ITS RELATION TO ACADEMIC INTEGRITY IN THE USA RESEARCHES
}

The paper deals with the idea of trust as value forming the base of academic integrity. The idea of academic integrity is closely connected with such important issue as quality of education in many ways, particularly by means of supporting trust between different stakeholders of educational process. The study of the positive and negative findings of US researchers in the field of atmosphere of trust development in the academic community becomes urgent for the educational institutions particularly in Ukraine. The main purpose of the paper is to describe the main trends of considering trust in the philosophic understanding and its relation to the system of values of academic integrity in the researches of US scholars. The three editions of "The Fundamental Values of Academic Integrity" contain the concept of trust as one of the values of academic integrity. The difference of representation of the notion of trust in the abovementioned editions shows the changes of the approaches to the issue and the concept of academic integrity in general. The idea of trust in the educational context is often considered from various points of view. It is not solely discussed as a part of academic integrity definition and support. Trust is an important concept forming the healthy relations in a society and thus in the educational institution as a form of social life. The whole academic community is involved into the process of building and maintaining trust. The main trends of considering trust in the philosophic understanding and its relation to the system of values of academic integrity in the studies of US scholars are determined by the concept of trust in the system of individual's moral values. Trust supports academic integrity from one hand and determines the quality and effectiveness of the whole academic community from the other hand.

Key words: trust, academic integrity, distance education, academic community, environment of trust.

Ольга НЕСТЕРОВА, orcid.org/0000-0002-5952-4664 кандидат педагогічних наук, доцент, доиент кафедри перекладу Національного технічного університету «Дніпровська політехніка» (Дніпро, Україна) olnesterova@yahoo.com

\section{ДОВІРА ТА АКАДЕМІЧНА ДОБРОЧЕСНІСТЬ У ДОСЛІДЖЕННЯХ НАУКОВЦІВ США}

У статті розглядається ідея довіри як иінності, щзо формує основу академічної доброчесності. Ідея академічної доброчесності багато в чому тісно пов'язана з таким важливим питанням, як забезпечення якості освіти на різних рівнях, зокрема шляхом підтримки довіри між різними зацікавленими сторонами навчального процесу. Вивчення позитивних та негативних висновків американських дослідників у галузі атмосфери розвитку довіри в академічній спільноті стає актуальним для навчальних закладів, особливо в Украӥні, щзо пов'язано із стрімкими трансформаціями системи освіти. Основною метою статті є опис основних тенденцій врахування довіри у філософському розумінні та ї̈ відномення до системи изіностей академічної доброчесності в дослідженнях американських вчених. Три видання «Фундаментальних иінностей академічної доброчесності» містять поняття довіри як однієі із иінностей академічної доброчесності. Різниия представленості поняття довіри у згаданих виданнях свідчить про зміни у підходах до проблеми та кониепиії академічної доброчесності загалом. Ідея довіри в освітньому контексті часто розглядається з різних точок зору. Це не обговорюється лише як частина визначення та підтримки академічної доброчесності. Довіра є важливою концепиією формування здорових відносин у суспільстві, а отже, і в освітньому закладі як формі соціального життя. Уся академічна спільнота бере участь у процесі побудови та підтримки довіри. Основні тенденції розгляду довіри у філософському розумінні та ії відношення до системи иінностей академічної доброчесності в дослідженнях вчених Сполучених Штатів Америки визначаються вихідною кониепиією довіри як системи моральних иінностей особистості. Довіра підтримує академічну доброчесність з одного боку, а з іншого визначає якість та ефективність всієї академічної спільноти.

Ключові слова: довіра, академічна доброчесність, дистанційна освіта, академічна спільнота, середовище довіри. 
Modern universities are in search of the ways of creation of supportive environment for students' high-quality learning and development. This results from the need to equip the graduates with the most important skills being useful for their future career and personal development, as well as the understanding the challenges of modern society and labour market to remain up-to-date in constantly changing conditions. The idea of academic integrity is closely connected with such important issue as quality of education in many ways, particularly by means of supporting trust between different stakeholders of educational process.

The relations and the ways of developing them are considered from different points of view by both educators and philosophers, as well as other scholars and practitioners. Trust is considered to be one of the values of academic integrity, but this concept is of multidimensional type, so not only concerns the issue of academic integrity, but also the general system of university environment.

Problem statement. The shades of trust as the base of relations at any educational institution are very different, they are considered by a range of educators and university authorities, in particular representing the universities of the United States of America. It is worth mentioning that their ideas may of great interest for the universities from other countries on their way to building the atmosphere of trust and integrity in the particular educational institution. The specific conditions of functioning of universities in the USA (multiculturalism, high variability of educational fields and so on) make their experience be valuable for other universities as a way of increasing the efficiency of their activities aimed at quality assurance by creating the high-level learning environment. So, the study of the positive and negative findings of US researchers in the field of atmosphere of trust development in the academic community becomes urgent for the educational institutions particularly in Ukraine.

Analysis of recent research and publications. This topic is not a kind of brand-new idea, the notion of trust was considered by researchers from different fields of knowledge. M. R. S. Covey searching for solutions of operational management problems described the levels of trust on the base of metaphorical image of waves created by a stone thrown into the water. The waves form circles of different diameters representing the spread of trust being as follows (Covey, 2006):

- Self Trust;

- Relationship Trust;

- Organizational Trust;

- Market Trust;
- Societal Trust.

The model is also usable for the representation of the general idea of trust atmosphere development in the institution of higher education. It covers the levels of trust building from the most concrete level to the most general one. M. Blaskova, R. Blasko, Z. Kozubikova and A. Kozubik based on the results of their study involving the numerous surveys of educational process stakeholders highlight that "the trust and positive relational atmosphere (reliability in relationship from the side of university teachers and staff) play an important role for the students, and can help in building perfect university - excellent students and teachers create the foundation of excellent (perfect) university" (Blaskova, Blasko, Kozubikova and Kozubik, 2015: 76).

The three editions of "The Fundamental Values of Academic Integrity" contain the concept of trust as one of the values of academic integrity. Its role is of great importance, as "an academic community of integrity fosters a climate of mutual trust, encourages the free exchange of ideas, and enables all to reach their highest potential" (The Fundamental Values of Academic Integrity, 1999). This approach was shared and supported by educational institutions and is often highlighted in their Academic Integrity Policy Statements and Codes of Ethics: "Because learning is a collaborative process, all stakeholders at Baker College have a reciprocal responsibility to ensure the academic community is grounded in honesty, trust, and respect" (Academic Integrity Philosophy).

The variety of studies concerning the idea of trust and academic community development in the USA has not been considered from the positions of generalizing and systematization, which would enable the creation of complex approach to the issue in Ukraine.

Purpose of the paper. The main purpose of the paper is to describe the main trends of considering trust in the philosophic understanding and its relation to the system of values of academic integrity in the researches of US scholars.

Research results. Trust is considered as inevitable element of academic integrity. According to Ali Darwish, "without integrity, trust cannot be built, but for integrity to be instilled in individuals, a culture of trust must be created. Low-trust institutions are perfect environments for dishonesty, deceit, and exploitation and integrity cannot be confined to a glossy brochure or an information kit" (Darwish, 2010). The author highlights the mutual dependence of the phenomena doing their distinction more complicated. But there also exist other points of view considering the strict hierarchy of the two notions mentioned. The idea of trust as a value of academic integrity was shown in 
each of three editions of "The Fundamental Values of Academic Integrity". It is worth mentioning that the role of activity component of trust increased in the third edition compared to the first one. The first edition points up the role of all members of academic community if trust maintenance: "Trust is also promoted by faculty who set clear guidelines for assignments and for evaluating student work; by students who prepare work that is honest and thoughtful; and by schools that set clear and consistent academic standards and that support honest and impartial research" (The Fundamental Values of Academic Integrity, 1999). The third edition shows developed idea of building trust by means of taking measures and supporting the "ways to demonstrate trust" being as follows:

- clearly state expectations and follow through;

- promote transparency in values, processes, and outcomes;

- trust others;

- give credence;

- encourage mutual understanding;

- act with genuineness (The Fundamental Values of Academic Integrity, 2021).

The second edition highlights the extremely important role of trust in the academic community: "Trust enables us to collaborate, to share information, and to circulate new ideas freely, without fear that our work will be stolen, our careers stunted, or our reputations diminished" (The Fundamental Values of Academic Integrity, 2014).

The difference of representation of the notion of trust in the abovementioned editions shows the changes of the approaches to the issue and the concept of academic integrity in general. But both sources point up the complexity of building the environment of trust in the educational institution. There is the idea that "instructors may choose not to employ such overt anti-cheating approaches and instead make that commitment to trust a cornerstone of their efforts to encourage academic honesty" expressed by the specialists from The Center for Teaching Excellence in Boston College (Choosing Trust). This is one of the ways of supporting academic integrity, i.e. instead of taking some extra measures to prevent cheating and other violations of academic integrity the educators may do nothing considering the students' attitude to the educational activities as trustworthy.

But anyway trust is the relations to be developed regardless to the level of education and the attitude towards academic integrity maintenance. LaKimbre Brown suggests the following recommendations for each educator to build the atmosphere of trust in the educational environment efficiently:

- plan it like you plan a lesson;
- focus on students as individuals;

- establish a peer support group (Brown LaKimbre).

American researcher Brene Brown considering the psychological aspects of trust suggests the BRAVING structure of trust, which supposes trust to be the unity of the following elements as:

- Boundaries;

- Reliability;

- Accountability;

- Vault;

- Integrity;

- Nonjudgment;

- Generosity (Brown B).

The author highlights the role of trust in the educational process and considers it as one of the educational goals being among the challenges all educators face during their professional activity. This problem becomes more complicated in modern conditions of blended and distance learning caused by the pandemics in 2020-2021. The educational activities are mediated by digital platforms, so the personal communication is at the minimal level. Y. Diana Wang has developed the "socio-technical framework of trust-inducing factors" (Wang, 2014: 11) to assess the prospective for trust building in e-learning. She has distributed the factors into four dimensions: credibility, design, instructor socio-communicative style, and privacy \& security (Wang, 2014: 11). The system of factors includes the following items:

1. Prior positive experience with the e-learning system or the instructor.

2. Good reputation of the e-learning system or the instructor.

3. High information and design quality of the e-learning system.

4. Good accessibility and usability of content and tools in the e-learning system.

5. Display of contact details of the instructor or the physical entity behind the e-learning system.

6. Assertiveness of the instructor.

7. Responsiveness of the instructor.

8. A sense of care and community created by the instructor.

9. Disclosure of understandable and adequate privacy and security policy statement.

10. Use of security mechanisms (e.g., the secure HTTP protocol, encryption, secured logging system, etc.).

11. Compliance with third-party privacy assurance or standard (e.g., US-EU \& US-Swiss Safe Harbor Frameworks, IEEE LTSC, etc.).

12. Reliable and timely access to the e-learning system (Wang, 2014: 11-12). 
The researcher uses the system of factor for the analysis of e-courses, but they may also be used to understand the important background for building the environment of trust and increase the level of academic integrity support by means of the proper organizational system of a particular course. The educator seeking for the improvement of their traditional and online courses would find the framework useful for doing SWOT analysis of their activities.

Lucie Cerna in the paper "Trust: What it is and Why it Matters for Governance and Education", a part of OECD Education Working Papers" based on the evidence of OESD countries, distinguishes the following functions of trust in the educational environment:

1. Trust is an important ingredient for policymaking and implementation, innovation and social and economic interactions in general.

2. Trust is necessary for increased collaboration between stakeholders, accountability as a way of improvement, greater professionalisation, coping with complexity and the reduction of asymmetries.

3. Conditions that are conducive to the emergence of trust should be selected, such as not placing too much focus on mistrustful means of governance. This can create positive feedback effects and lead to virtuous cycles.

4. Trust takes time to develop, but can break down easily. Facilitating open communication, transparency and cooperation, and prevent the abuse of power can avoid breakdowns in trust.

5. A whole system reform of education systems cannot take place without a respected and trusted teaching profession. To build trust, respect in the profession (or stakeholders in general) is the first step, trust and competencies will follow over time (Cerna, 2014).

The idea of trust as an important component of educational environment is based on the general idea of trust being the moral value. As E. Uslaner states, "trust matters for the sorts of things that bond us to others without expectations of reciprocity-giving to charity, volunteering time, tolerance of minorities, and promoting policies that redistribute resources from the rich to the poor (Uslander, 2001). The activities of educational institutions are based on the needs of society, so they also share and support the values peculiar to the society.

The idea of trust in the educational context is often considered from various points of view. It is not solely discussed as a part of academic integrity definition and support. Trust is an important concept forming the healthy relations in a society and thus in the educational institution as a form of social life.

The whole academic community is involved into the process of building and maintaining trust: "An academic community of integrity fosters a climate of mutual trust, encourages the free exchange of ideas, and enables all to reach their highest potential" (The Fundamental Values of Academic Integrity, 1999). The climate of trust influences the quality of functioning of academic community, as well its relations with the "outer" world building the positive image of the proper educational institution in the society and even in the whole world community.

Conclusions and prospective for further studies. The idea of trust as a value of academic integrity is based on the perception of trust as moral and social value being crucial for the existence of society and its elements. The main trends of considering trust in the philosophic understanding and its relation to the system of values of academic integrity in the studies of US scholars are determined by the concept of trust in the system of individual's moral values. Trust supports academic integrity from one hand and determines the quality and effectiveness of the whole academic community from the other hand.

The concept of trust is a kind of complex multidimensional notion, so its consideration uncovers a range of important issues to be discussed. In the context of the present study we may mention the problem of building and support trust in the conditions of distance and blended learning, as the findings of previous investigations demonstrate a range of challenges to be coped with.

\section{BIBLIOGRAPHY}

1. Academic Integrity Philosophy. URL: https://www.baker.edu/policies-and-procedures/academic-integrity-philosophy

2. Blaskova M., Blasko R., Kozubikova Z., Kozubik A. Trust and reliability in building perfect university. Procedia Social and Behavioral Sciences. 2015. № 205(2015). P. 70-79.

3. Brown B. The BRAVING Inventory URL: https://brenebrown.com/downloads/

4. Brown LaKimbre. The Importance of Trust. URL: https://teachforall.org/news/importance-trust

5. Choosing Trust. URL: https://cteresources.bc.edu/documentation/cultivating-academic-integrity/instructionalresponses-to-academic-dishonesty/limiting-opportunities-for-academic-dishonesty/choosing-trust/

6. Cerna L. Trust: What it is and Why it Matters for Governance and Education. OECD Education Working Papers, No. 108, OECD Publishing, 2014. http://dx.doi.org/10.1787/5jxswcg0t6wl-en

7. Covey M. R. S. The speed of trust: The one thing that changes everything. New York, NY: Free Press, 2006. 
8. Darwish A. The Teabag of Trust and Academic Integrity. At-turjuman Online. URL:https://www.researchgate.net/ publication/312471935_The_Teabag_of_Trust_and_Academic_Integrity

9. The fundamental values of academic integrity. Des Plaines: Oakton Community College, 1999.

10. The fundamental values of academic integrity. 2nd ed./ ed. T. Fishman (Ed.). Clemson: Clemson University, 2014. https://doi.org/10.15713/ins.mmj.3

11. The fundamental values of academic integrity. 3rd ed. / International Center for Academic Integrity [ICAI]. 2021. URL: www.academicintegrity.org/the-fundamental-valuesof-academic-integrity

12. Uslaner E. M. Trust in the Knowledge Society. URL: http://gvptsites.umd.edu/uslaner/uslanermoralfoundations.pdf

13. Wang D. Building Trust in E-Learning. Athens Journal of Education, 2014. Vol. 1, Issue 1. P. 9-18.

\section{REFERENCES}

1. Academic Integrity Philosophy. URL: https://www.baker.edu/policies-and-procedures/academic-integrity-philosophy

2. Blaskova M., Blasko R., Kozubikova Z., Kozubik A. Trust and reliability in building perfect university. Procedia Social and Behavioral Sciences. 2015. № 205(2015). P. 70-79.

3. Brown B. The BRAVING Inventory URL: https://brenebrown.com/downloads/

4. Brown LaKimbre. The Importance of Trust. URL: https://teachforall.org/news/importance-trust

5. Choosing Trust. URL: https://cteresources.bc.edu/documentation/cultivating-academic-integrity/instructionalresponses-to-academic-dishonesty/limiting-opportunities-for-academic-dishonesty/choosing-trust/

6. Cerna L. Trust: What it is and Why it Matters for Governance and Education. OECD Education Working Papers, No. 108, OECD Publishing, 2014. http://dx.doi.org/10.1787/5jxswcg0t6wl-en

7. Covey M. R. S. The speed of trust: The one thing that changes everything. New York, NY: Free Press, 2006.

8. Darwish A. The Teabag of Trust and Academic Integrity. At-turjuman Online. URL:https://www.researchgate.net/ publication/312471935_The_Teabag_of_Trust_and_Academic_Integrity

9. The fundamental values of academic integrity. Des Plaines: Oakton Community College, 1999.

10. The fundamental values of academic integrity. 2nd ed./ ed. T. Fishman (Ed.). Clemson: Clemson University, 2014. https://doi.org/10.15713/ins.mmj.3

11. The fundamental values of academic integrity. 3rd ed. / International Center for Academic Integrity [ICAI]. 2021. URL: www.academicintegrity.org/the-fundamental-valuesof-academic-integrity

12. Uslaner E. M. Trust in the Knowledge Society. URL: http://gvptsites.umd.edu/uslaner/uslanermoralfoundations.pdf

13. Wang D. Building Trust in E-Learning. Athens Journal of Education, 2014. Vol. 1, Issue 1. P. 9-18. 